\title{
The use of electronic learning centres in public libraries in the city of Johannesburg, South Africa
}

\author{
Sifiso Michael Mbambo, Glenrose Velile Jiyane and Nkosingiphile Mbusozayo Zungu
}

\section{Introduction}

The availability of electronic learning centres in public libraries plays a huge role in remodelling training and leisure. Abumandour (2020) points out the role of public libraries in spreading and supporting the electronic learning system. This topic has recently been examined in the literature from many perspectives (Abbasi and Zardary, 2012; Han and Yates, 2016; Kumbhar, 2009). Abbasi and Zardary were interested in the role of public libraries in supporting electronic learning. This includes the use of electronic learning centres for the provision of public access to the internet, tablets, computers and electronic learning programmes. Electronic learning centres encourage resource-sharing for the underresourced libraries.

Normally electronic learning centres in public libraries have an opportunity to provide users with open online courses, a venue for learning, effective learning content through the shift to mobile technologies and the paradigm shift from textbooks to mobile devices. Access to electronic learning centres has enhanced service delivery in most public libraries (Dzandza, 2019:79).

Abumandour (2020) states that electronic learning centres in public libraries could provide both digital resources to support e-learning. Public

(C) Sifiso Michael Mbambo, Glenrose Velile Jiyane and Nkosingiphile Mbusozayo Zungu. Published by Emerald Publishing Limited. This article is published under the Creative Commons Attribution (CC BY 4.0) licence. Anyone may reproduce, distribute, translate and create derivative works of this article (for both commercial and noncommercial purposes), subject to full attribution to the original publication and authors. The full terms of this licence may be seen at http://creativecommons.org/ licences/by/4.0/legalcode libraries with electronic learning centres functions better as the centres enhance the services available for users, according to the National Science Teachers Association (NSTA, 2016). The most outstanding breakthrough was achieved in both the science and technology fields (NSTA, 2016). Therefore, innovative and advanced electronic learning systems have lately attracted more attention Chetty (2012) and Eagleton and Manolopoulou (2017).

\section{E-learning centres in Johannesburg public libraries}

The study was conducted in public libraries within the city of Johannesburg. The city of Johannesburg metropolitan municipality is located in the Gauteng province of South Africa and serves a total of 4.9 million people (South Africa. Statistics South Africa, 2016). The current population makes it the biggest metropolitan municipality by population size in South Africa. The city of Johannesburg library and information services (COJLIS) forms part of community development under the city's human and social development cluster. COJLIS is expected to contribute programmes that address some of the cluster's mandates such as illiteracy, lack of information literacy skills, increasing digital citizenry in the fourth industrial revolution era by bridging the digital divide, implementing e-learning programmes (city's smart city's strategy) and inequality with regard to library service provision (Mpendulo and Ramela, 2018:4).

Johannesburg oversees and manages 90 public libraries and three support sections responsible for delivering library services to its 4.9 million residents. Johannesburg introduced electronic learning centres in public libraries because of the increasing number of population and users, as well as increasing demand for better, convenient and feasible ways to enhance library services. It is important to note that it was only in the 1970s that the Johannesburg public library opened its doors to black users (Issak, 2000; Mhlongo, 2018, p. 24) who are often unaware of electronic learning centres in public libraries. Although much research has been conducted on services in public libraries. Dzandza (2019, p. 60) observed that libraries in Africa that had implemented electronic learning generally experienced underutilisation of the technology on account of the lack of sound information technology exploitation skills. Evans and Le Roux (2015: 26), inciting E-learning Africa (2012), revealed that $42 \%$ of respondents attest to the use of ICT enhanced devices for teaching and learning. The report showed that $83 \%$ of the respondents used laptops, and $71 \%$ used mobile phones, which are ranked the most popular learning devices than smartboards, virtual desktops and tablets.

Balapanidou (2015) opined that e-learning started around October 1999 at the CBT systems seminar in Los Angeles, at the seminar where the word "e-learning services" was used for the first time. This is interchangeably used as "online learning" or "virtual learning". Supporting this contention by Leerbeleving, Abumandour (2020) explains that e-learning has existed since 1999 when the CBT systems seminar used the word for the first time. However, little is known about the use of electronic learning centres particularly when users are not aware of their existence and benefits.

Public libraries in the city of Johannesburg have adopted the use of electronic learning to improve services to the users $(2018 / 19)$. However, the electronic learning centres are 
exacerbated by connectivity issues and inconsistency of access to the internet. Users find it difficult to access and complete tasks when using electronic learning centres. The goal of this review is to identify different services available and accessible in the electronic centres and to determine the level of awareness and training on the use of the electronic learning centres and their resources.

Review of E-learning library services the study was informed by the technology acceptance model (TAM) to determine the use of electronic learning centres by users at Johannesburg city libraries. Ocholla and Le Roux (2011, p. 1) define a theoretical framework as "The structure that holds and supports the theory of a research work. It serves as the lens that the researcher uses to examine a particular aspect of his or her subject field." TAM is a theoretical extension of the theory of reasoned action (TRA). TRA originated from social psychology and generalises explanations of a number of individual behaviours (Lee et al., 2011, p. 356). Based on the TRA, Davis (1989) introduced TAM, which is a modified model and focuses on the user acceptance of computer technology (Zhang et al., 2014, p. 300).

TAM is a research tool that can assist in explaining and predicting users' adoption of a system, which for the study is electronic learning (Zhang et al., 2013, p. 1030). Acceptance is the willingness of individuals to use an IT system for the tasks it is designed to perform (Camarero et al., 2012, p. 5). TAM theory states that behaviour is defined by two typical determinants of behavioural intention, which are attitude and subjective norm.

According to Opeyemi (2018, p. 20), the value of e-learning centres in the library is determined not only by the depth and breadth of its contents and to be a place of interchange, learning, tolerance and understanding (Proudfoot and Kebritchi, 2017).

Following are the main services provided by the electronic learning centres in public libraries:

Users can access the internet, Wi-Fi through their centre library computers occasionally (Opeyemi, 2018, p. 134). Public libraries have improved their services through electronic learning. The extensive use of the internet and the Web has changed information generation, storage and retrieval methods (Opeyemi, 2018, p. 2) and increased the demand for electronic learning centres for library users. This is regardless of users' location distance and time barriers within the country, which has been surmounted.

Library users can access online resources that are subscribed to by public libraries, such as e-books, online newspapers and articles from our electronic resources collection (Moyo, 2017, p. 18). Electronic resources can be remotely accessed through desktop computers and different mobile devices like mobile phones, palmtops, laptops, notebooks, iPads and other miniature devices. According to Opeyemi (2018, p. 2), electronic learning centres at the public library can host a mobile electronic resource library bringing education to the remotest part of the world where knowledge is sought.

Patrons can type their work, print and make copies at the electronic learning centres. The core aim of this service is to enable public libraries' electronic learning centres users (from all over Africa and worldwide) to access services available in these electronic learning centres (Abumandour, 2020). Most of the electronic library resources are online, and therefore, a user would require internet connectivity to access them (Moyo, 2017, p. 81). Furthermore, some users may require to print some of the accessed materials for future reference.

Techno-literacy training is provided to library staff to give them all the necessary skills to be able to assist users (Mpendulo and Ramela, 2018). The library staff trained on programmes electronic learning programmes such as Siyafunda, Goethe M-Literacy, Microsoft, IBM, Vodacom, FunDza Literacy Trust and Google SA (Mpendulo, 2017). These skills are imparted to users by librarians when helping users. Furthermore, the programmes offered to educate users on the concept of self-learning and increase their desire to develop themselves. The service provides users with long-term scholastic services at any time and from any location (Proudfoot and Kebritchi, 2017). The electronic learning services are designed to give users' access to MOOCs, online courses and other electronic learning modules. Furthermore, electronic learning services strive to deliver electronic learning courses in a variety of areas, not limited to LIS (Abumandour, 2020). Public libraries improve their electronic learning resources, techniques and materials indoors and are keen to collaborate with other informative organisations and institutions.

The importance of awareness in the lives of library users cannot be overstated (Opeyemi, 2018, p. 17). To develop knowledge and skills of use, users must be aware of several elements such as typing, printing, photocopying and scanning in electronic centres (Moyo, 2017, p. 2). Despite its importance in contemporary socio-cultural learning theories, the importance of social awareness in electronic learning has recently been examined (Lambropoulos et al., 2012). Ncube (2015, p. 17) opinion that efficient electronic learning centres should take into account not only information and knowledge transmission but also social and dialogical interactions among users. Therefore, the design of such environments determines the kinds of social interactions that can occur, and thus, can facilitate or impede learning.

Ncube $(2015$, p. 18) is of the same view as the researcher because they also reveal the awareness of e-learning as important in learning activities contexts for understanding electronic learning centres, and users' activity contexts can reflect their own profile in knowledge, social and technical dimensions through using the electronic centres in public libraries. The researcher noted that if users frequently visit electronic learning centres in public libraries, it may be presumed that the users are interested and aware of electronic learning centres.

Training is important in the lives of users of any library services or facilities in the library (Eagleton and Manolopoulou, 2017). Users can be trained in various aspects such as Overdrive (e-books), www.jurn.org (e-journals, e-theses and dissertations), Pressreader (e-magazines, e-newspapers), e-research reports, e-bibliographic databases, E-Britannica, World Wide Web (WWW), conference proceedings in order that they gain knowledge and skills of use (Moyo, 2017, p. 26; city of Johannesburg case study 2018/19). Computing, digital, technical and information literacy competencies are required to access and use electronic 
learning centres (George and Frank, 2004; Sujatha and Murthy, 2010; Moyo, 2017 , p. 30). Digital literacy, according to Khan and Waheed (2015), is the knowledge and comprehension of digital media that allows one to work effectively with digital media in an electronic learning environment. As a result, users who lack information literacy but are computer literate are more likely to use electronic learning centres than users who are information literate but lack computer skills (Moyo, 2017, p. 31).

A quantitative research approach was adopted, and questionnaires were used to collect primary data from the respondents. The target population was the entire users of the electronic learning centres and librarians. The probability sampling technique was adopted to select 24 librarians and 60 users from Sandton Library (Region E) and Johannesburg City Library (Region $\mathrm{F})$, providing services in and using these centres in the public libraries within the city of Johannesburg. The two libraries are known as regional libraries of Johannesburg due to their capacity and resources. Other regions were not included in this paper due to low response, and data collection process is still ongoing. The users were targeted because they specifically use the electronic learning centres for purposes such as career growth, personal and studying online or offline. Including librarians working in the section of the electronic learning centres was critical because they are assigned with the duty and responsibility for monitoring and making sure the electronic learning centres are available, accessible, protected, reliable and authentic to use. They were all selected through stratified sampling due to their homogenous strata of use of electronic centres from the whole public libraries' users. In a stratified sampling, different groups of the population have sufficient representation in the sample, as stated by Creswell and Creswell (2018, p. 150). The sampling method chosen for this study was stratified sampling, as it is applied when the sample reflects the true proportion in the population of individuals with certain characteristics (Etikan and Bala, 2017). It was used to obtain a representative of a good sample due to users' homogenous strata of use of electronic centres from the entire public libraries' users and librarians.

The questionnaires distributed to the library users and librarians were 74 in total; only 55 questionnaires were returned, giving a $74 \%$ response rate. Quantitative data were analysed using descriptive statistics, which generated tables, frequencies and percentages. To determine different services available and accessible, users of Sandton Library (Region E) and Johannesburg City Library (Region F) were asked the following questions on electronic learning centres. Librarians were also asked what services the users prefer from the library electronic centres.

Users provided multiple responses about their reasons for accessing electronic learning services at the library. The majority $(27 ; 82 \%)$ of respondents access electronic learning services free $\mathrm{Wi}-\mathrm{Fi}$, followed by 21 respondents (64\%) who access electronic learning services for internet access. A further $20(60 \%)$ access electronic learning services for laptops. Seven respondents $(21 \%)$ for typing. Only six (18\%) access electronic learning services for computers. Five (15\%) preferred to access electronic learning services for USBs and five (15\%) for printers. Four (12\%) access electronic learning services for scanners and three $(9 \%)$ for electronic resources. Although another three (9\%) for photocopiers. It was interesting to note that only two (6\%) preferred to access electronic learning services for headsets and one $(3 \%)$ for CDs. The findings indicate that most of the users made use of the electronic learning services centres because of $\mathrm{Wi}-\mathrm{Fi}$, internet access and laptops services. They are in line with Goulding's (2016, p. 109) observation that library users use library facilities to access library resources and electronic learning services not available in other institutions.

To determine why users' access electronic learning centres, library staff were asked an open-ended question about the types of electronic learning services users ask for when accessing the electronic learning centres. The following were their responses. The results show that the majority $(27 ; 82 \%)$ of respondents' prefer to use electronic learning services for work, followed by 21 respondents $(64 \%)$ who prefer electronic learning services for internet access and Wi-Fi. A further $20(60 \%)$ prefer to use electronic learning services for laptops and search for employment. Seven respondents $(21 \%)$ for typing and scanning. Only six (18\%) use electronic learning services for research purposes. Five (15\%) preferred to use electronic learning services for leisure, and five $(15 \%)$ because they are user-friendly and accessible. Apart from the services listed above, the library staff also kept registers for users accessing electronic learning services and no library card is required for easy access to the library electronic learning centres.

The response on how users are made aware of services in the electronic learning centres was, the majority of $(18 ; 54 \%)$ of respondents' that personal discovery electronic learning services, followed by four respondents (12\%) from friends. A further 18 (54\%) were made aware by library staff about electronic learning services. A total of 12 respondents $(36 \%)$ were made aware by other electronic learning centre users. Only two (6\%) discovered electronic learning services from user orientation. Eight (24\%) became aware through the electronic library webpage about electronic learning services and twelve $(36 \%)$ through social media tools. The findings indicate that most of the users became aware of the electronic learning services centres through personal discovery, library staff and other electronic learning centre users and through social media tools. Mamafha (2013, p. 105) also conducted a study in the use of ICTs at Ekurhuleni municipal libraries, in which users were made aware by the staff members on electronic learning services when seeking help, particularly first-time users of ICTs who rely on staff for guidance.

The majority of the users who responded to the survey, $27 \%(n=14)$, rated personal discovery most effective, followed by $6 \%(n=3)$ friends, $34 \%$ $(n=18)$ library staff most effective, $33 \%$ $(n=17)$ through social media tools most effective. The rate of respondents indicated that most users got to know about electronic learning centres through library staff, through social media tools and personal discovery.

A total of 22 library staff response on tools used to create awareness on electronic learning centres was, the majority $(16 ; 43 \%)$ of respondents' the 
library use Facebook to create awareness about electronic learning services, followed by 15 respondents (41\%) library use notice boards for awareness of electronic learning centres. Three $(8 \%)$ library handouts are used for awareness of electronic learning centres and three $(8 \%)$ for flyers. According to, Mamafha (2013, p. 38), libraries attract a lot of users, and the board planned to expand the service both at libraries in the network to meet the ever-increasing user needs, as the people become more aware of the power of Facebook as a source of information and knowledge. The findings indicate that Facebook and notice boards are the most used to create awareness of electronic learning centres.

Library staff was asked to rate their skills on electronic learning on a scale of $1-5,1$ being "very poor" and 5 being "very good." The respondents rated "very good" on computers and free Wi-Fi with $(21 ; 95 \%)$ followed by free Wi-Fi with 21 (63\%) and typing with 12 respondents, which received a rating of $55 \%$. While photocopying received average ratings of $50 \%$, with 11 respondents. Electronic resources and printing skills were rated $45 \%$, with 10 respondents each. The findings indicate that computers and free $\mathrm{Wi}-\mathrm{Fi}$ were rated the most appropriate skills that library staff has.

In response to training received by library staff $(95.5 \%)$ of the 22 respondents to this question indicated that they received training, whereas $4.5 \%(n=1)$ indicated that they did not receive training on electronic learning centres services, the library staff was asked about the training they received, the majority $(20 ; 91 \%)$ of respondents' received training on electronic learning programmes, followed by 19 respondents $(86 \%)$ who received electronic resources training. A further $14(64 \%)$ received training on internet, Power Point and Microsoft Access. Only 13 respondents $(59 \%)$ indicated that they had received training on Microsoft Word.

It was important for this study to determine the enhancement of using electronic learning centres in the public libraries of the city of Johannesburg. The question was open-ended, where each user had to state their opinion. The results revealed different answers and are presented below:
- $\quad$ more laptops are needed, strengthen internet connectivity and do more marketing on e-learning centres;

- host regular e-learning programmes and give the public the necessary skills needed for using the e-learning machinery and having more librarians to assist;

- more awareness, regular updates on notice boards, flyers, notices directing to the site;

- $\quad$ stable internet access and capacity of equipment (devices);

- it should cover both literate and illiterate clients to bridge the digital divide, providing adequate programs and awareness of library e-learning centres;

- $\quad$ security update must be done for libraries, and more resources must be bought;

- training programs and tech-savvy librarians; and

- e-learning centres must reopen because most are closed due to COVID-19 regulations. Measures must be put in place as per COVID-19 regulations. Wi-Fi and internet must be upgraded to strengthen connectivity.

The library staff response is, there should be adequate ICT services and resources, more funding, management support, facilitate more training programmes and skills development for library personnel. According to Snead (2014, p. 467), public libraries frequently lack the resources needed to adequately develop library technology solutions and train personnel to deliver services, or they lack government financial support for service development and delivery.

\section{Conclusions}

This quantitative study reports on the preliminary results from only two regions in the city of Johannesburg public libraries, and it sought to establish the use of electronic learning centres. The findings reveal services available and accessible in the electronic learning centres are user-friendly and are optimally used by many users.

The level of awareness of the electronic learning centres is high. However, in terms of training on the use of the electronic learning centres and their resources, the findings revealed that there is a need for staff training and users, the internet is too slow, lack of management support and electronic learning centres are limited and closed due to COVID-19 regulations. This study also revealed that more resources (computers and laptops) are required in electronic learning centres.

The study recommends that libraries should: train library staff in tech-savvy non-traditional library services, such as the use of Pressreader and Siyafunda; do more awareness programmes on electronic learning centres, purchase relevant equipment for electronic learning centres, management must support electronic learning services, strengthen the internet connection and ensure that there are adequate services and resources always. Finally, it recommends that the city of Johannesburg libraries to expand electronic learning centres to other libraries to accommodate all its users throughout the city.

\section{REFERENCES}

Abbasi, F. and Zardary, S. (2012), "Digital libraries and its role on supporting E-learning AWERProcedia information technology and computer science", Academic World Education and Research Center, Vol. 7, pp. 809-813.

Abumandour, E.-S.T. (2020), "Public libraries' role in supporting e-learning and spreading lifelong education: a case study", Journal of Research in Innovative Teaching \& Learning, Vol. 14 No. 2, pp. 178-217, doi: 10.1108/JRIT-06-2019-0063, (accessed 23 July 2021).

Balapanidou, A. (2015), "The challenging role of public libraries as providers of lifelong learning opportunities for personal and social skills development", International Journal of Teaching and Education, Vol. III No. 2, pp. 1-16, doi: 10.20472/TE.2015.3.2.001.

Camarero, C., Rodríguez, J. and San José, R. (2012), "An exploratory study of online forums as a collaborative learning tool", Online Information Review, Vol. 36 No. 4, pp. 1-25, doi: 10.1108/146845 21211254077 , (accessed 03 September 2021).

Chetty, L.R. (2012), "The role of science and technology in developing world in the 21st century", Institute for Ethics and Emerging Technologies. Ethical Technology, available at: https://ieet.org/index.php/IEET2/more/ chetty20121003 (accessed 20 July 2021).

Creswell, J.W. and Creswell, J.D. (2018), Research Design: Qualitative, Quantitative, 
and Mixed Methods Approaches, 5th ed., Sage publications Ltd.

Dzandza, P.E. (2019), "Use and management of information systems in academic libraries in Ghana: University of the Western Cape", South Africa, Masters Dissertation, University of Western Cape.

Eagleton, C. and Manolopoulou, A. (2017), "Paper money of England and Wales", available at: www.britishmuseum.org/research/ publications/online_research_catalogues/ paper_money/paper_money_of_england_ wales/the_industrial_revolution/the_industrial _revolution_3.aspx (accessed 23 July 2021).

E-learning Africa (2012), "E-learning Africa report", available at: www.elearning-africa. com/pdf/report/ela_report_2012.pdf (accessed 23 July 2021).

Etikan, I. and Bala, K. (2017), "Sampling and sampling methods", Biom Biostat Int J, Vol. 5 No. 6, p. 149, doi: 10.15406/ bbij.2017.05.00149.

George, L. and Frank, I. (2004), "Beyond books - library services to distance education students", in Brindley, J. E. Walti, C. and Zawacki-Richter, O. (Eds), Library Services to Distance Education Students, Oldenburg, Biblioteks- und Informationssystem der Universität Oldenburg, pp. 139-143.

Goulding, A. (2016), Public Libraries in the 21st Century: defining Services and Debating the Future, Farnham, Ashgate.

Han, Y. and Yates, S. (2016), "eLearning integration in the library: a case study", Library Management, Vol. 37 Nos 8/9, pp. 441-453, doi: 10.1108/LM-04-2016-0025.

Khan, S.A. and Waheed, A. (2015), "Digital literacy practices for library users at government college university libraries", Lahore. Pakistan Library \& Information Science Journal, Vol. 46 No. 4, pp. 50-54.

Kumbhar, R. (2009), "Use of E-learning in library and information science education", DESIDOC Journal of Library \& Information Technology, Vol. 29 No. 1, pp. 37-41, doi: 10.14429/djlit.29.228.

Lambropoulos, N., Faulkner, X. and Culwin, F. (2012), "Supporting social awareness in collaborative e-learning", British Journal of Educational Technology, Vol. 43 No. 2, pp. 295-306, available at: http://web.b. ebscohost.com/ehost/pdfviewer/pdfviewer?sid= 947c059d-39d6-4521-b7e2-97eff9ae3477\% 40sessionmgr112\&vid=1\&hid=106 (accessed 23 July 2021)

Lee, Y., Hsieh, Y. and Ma, C. (2011), "A model of organizational employees' e-learning systems acceptance", KnowledgeBased Systems, Vol. 24 No. 3, pp. 355-366, doi: 10.1016/j.knosys.2010.09.005, (accessed 23 August 2021).

Mamafha, T.M.M. (2013), "Utilization of information and communication technologies in public libraries at ekurhuleni metropolitan municipality, South Africa. Pretoria: University of South Africa", Masters Dissertation, University of South Africa.

Mhlongo, M.A. (2018), "Integration of indigenous knowledge into the services of public libraries in South Africa", D Ed thesis, University of South Africa, Pretoria.

Moyo, M. (2017), “Awareness and usage of electronic library resources in open distance learning by third-year students in the school of arts at the university of South Africa Pretoria", Masters Dissertation, University of South Africa.

Mpendulo, N. (2017), Presentation of the Strategic Plan 2017-18 of the Library and Information Services to Community Development Department, City of Johannesburg, 18 September, Johannesburg.

Mpendulo, N. and Ramela, B. (2018), "Collaboration and sponsorship: Johannesburg public library eLearning programme", Paper presented at the 19th conference of the Library and Information of South Africa (LIASA) Conference, 09-12 October, International Convention Centre, Cape Town, South Africa.

Ncube, L.S. (2015), "Students' perceptions of e-learning in the department of information science at the university of South Africa pretoria", Masters Dissertation, University of South Africa.

Ocholla, D.N. and Le Roux, J. (2011), "Conceptions and misconceptions of theoretical frameworks in library and information science research", Paper presented at the 6th ProLISSA conference, Pretoria, 9-11 March.

Opeyemi, O.B. (2018), “Access to and use of library electronic resources at the national open university of Nigeria university of South Africa, pretoria", Masters Dissertation, University of South Africa.

Proudfoot, D.E. and Kebritchi, M. (2017), "Scenario-based E-learning and STEM education: a qualitative study exploring the perspectives of educators", International Journal of Cognitive Research in Science, Engineering and Education (Education), Vol. 5 No. 1, pp. 7-18, doi: 10.5937/ ijcrsee $1701007 \mathrm{p}$.
Snead, J.T. (2014), "Public libraries, evaluation and e-government", The Library Quarterly, Vol. 84 No. 4, pp. 467-480.

South Africa. Statistics South Africa (2016), "Community survey 2016", available at: http:// statssa.gov.za (accessed 22 July 2021).

Sujatha, H.R. and Murthy, S., H. (2010), "End-user training on the utilization of electronic information sources in fisheries sciences institutions in South India", The Electronic Library, Vol. 28 No. 5, pp. 741-753, available at: http://search. ebscohost.com/login.aspx?direct=true $\& \mathrm{db}=$ cin20\&AN=2010931598\&lang=es\&site=ehostlive (accessed 23 July 2021).

Zhang, S., Gao, P. and Ge, Z. (2013), "Factors impacting end-users' usage of ERP in China", Kybernetes, Vol. 42 No. 7, pp. 1029-1043, available at: www. emeraldinsight.com/journals.htm?articleid= 17101189 (accessed 06 July 2021).

Zhang, L., Nyheim, P. and Mattila, A.S. (2014), "The effect of power and gender on technology acceptance", Journal of Hospitality and Tourism Technology, Vol. 5 No. 3, pp. 299-314, doi: 10.1108/JHTT-032014-0008, (accessed 10 July 2021).

\section{FURTHER READING}

City of Johannesburg (2018/19), "Case studies: group strategy", Policy Coordination and Relations Innovation and Knowledge Management Unit, City of Johannesburg.

Johannesburg City Library (2012), A Commemorative Publication on the Occasion of the Re-Opening of the Johannesburg City Library on the 14 February 2012, Brochure, Johannesburg.

Sifiso Michael Mbamboa (mbambo6251@gmail.com) is based at the Department of Information Studies, University of Zululand, KwaDlangezwa, South Africa.

Glenrose Velile Jiyane (JiyaneG@ unizulu.ac.za) is based at the Department of Information Studies, University of Zululand, KwaDlangezwa, South Africa.

Nkosingiphile Mbusozayo Zungu (ZunguNM@unizulu.ac.za) is based at the Department of Information Studies, University of Zululand, KwaDlangezwa, South Africa. 